\title{
Thermal Analyses of Boric Acid Esters of 2-Tridecanol
}

Nagaaki Takamirsu, Toshikazu Hamamoto and Taichiro Nishi

Central Research Institute, Ube Industries, Ltd. ; Ube-shi, Yamaguchi, Japan

By the reaction of 2-tridecanol with metaboric acid in various mole ratios, three species of boric acid esters were prepared, and these esters were ascertained to be tri-2-tridecoxyboroxine [1], di-2-tridecoxyhydroxyborane[2], and tri-2-tridecylborate[3].

Thermal decomposition of these esters proceeded according to the first order law, and the initial decomposition rate constants were as follows:

$$
\begin{aligned}
& \text { for [1], } 4.82 \cdot 10^{7} \exp \left(-22.8 \cdot 10^{3} / R T\right) \mathrm{min}^{-1} \\
& \text { for [2], } 9.27 \cdot 10^{2} \exp \left(-11.0 \cdot 10^{3} / R T\right) \mathrm{min}^{-1} \\
& \text { for [3], } 1.55 \cdot 10^{3} \exp \left(-11.2 \cdot 10^{8} / R T\right) \mathrm{min}^{-1}
\end{aligned}
$$

The yields of main products by the thermal decomposition of these esters were as follows:

$96.2 \%$ tridecene from [1], 57.2\% tridecene and $40.6 \%$ tridecanol from [2], and $49.2 \%$ tridecene and 47.2 tridecanol from [ 3 ].

It was found that the thermal behavios of tri-2-tridecoxyboroxine are different from those of the other esters.

\section{ロジウム錯体触媒によるエチレンの三量化反応 ${ }^{1)}$}

\author{
(1971 年 8 月 18 日受理)
}

$$
\text { 大倉一郎・慶伊 富 長* }
$$

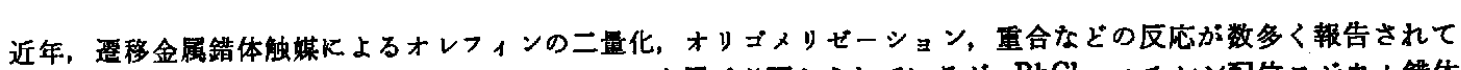
いる。錯体触蝶の活性種形成には多くの揚合フルキル金属が必要とされているが, $\mathrm{RhCl}_{3}$, エチレン配位ロジムム錯体 $\left[\mathrm{RhCl}\left(\mathrm{C}_{2} \mathrm{H}_{4}\right)_{2}\right]_{2}$ はフルキル金属の非存在下でオレフィンの二量化活性を有する。この錯体触媒によるエチレンの二番

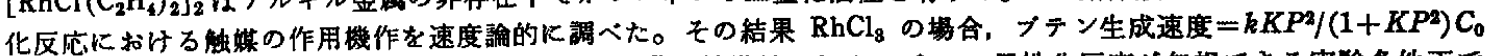

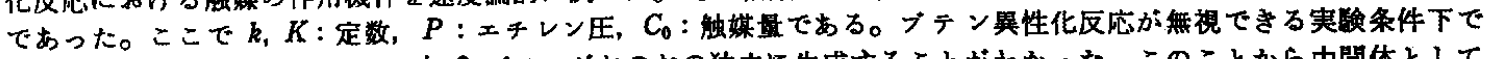
は 1-ブテン, trans-2-ブテン, cis-2-ブテンがおのおの独立に生成することがわかった。このことから中閏体として $\pi$ アンリル型を考えた。

一方, $\left[\mathrm{RhCl}\left(\mathrm{C}_{2} \mathrm{H}_{4}\right)_{2}\right]_{2}$ 触某の場合, 反応初期火おいては1-ブテンのみ生成し，ついで異性化により trans-2ブテンと cis-2-ブテンがほ注当モルの割合で生成する。さらに二量化反応速度はェチレン压に一次であることから，

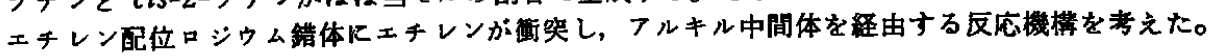

\section{1 楮}

金屬ーアルキル結合閪へのオレフィンの挿入反応は重合反心, アルキル化反応，二量化反応の素反応の一つとして興味がすたれ ている。この観点から,エチレンの $\mathrm{TiBu}_{4}-\mathrm{AlEt}_{3}$ 触媒による二 量化反応 ${ }^{2)}$ ， $\mathrm{TiCl}_{4}-\mathrm{Me}_{3} \mathrm{Al}_{2} \mathrm{Cl}_{3}$ または $\mathrm{MeTiCl}_{8}-\mathrm{MeAlCl}_{2}$ 触媒に よるオリゴメリゼーションが報告されている゙3。同様に $\pi-\mathrm{C}_{8} \mathrm{H}_{5}$. $\mathrm{NiX}\left(\mathrm{PR}_{3}\right)-\mathrm{AlBr}_{3}$ あるいは $\pi-\mathrm{C}_{3} \mathrm{H}_{5} \mathrm{NiX}\left(\mathrm{PR}_{9}\right)-\mathrm{AlEtCl}_{2}$ 触媒は $\alpha-$ オレフィンを選択的に二量化するが，その活性と選択性はRに依

1）この諭文を“ロジウム錯体蜰媒の作用機構（第 1 報）”とす る.

* 東宗工業大学工学部, 東京都目黒区大岡山

2) H. Martin, Angew. Chem., 68, 306(1956).

3) H. Bestian, K. Clauss, H. Jensen, E. Prinz, ibid., 74, 955(1962).
存することが知られている゙。これらの触媒禾はすべて助触葉と してアルキルアルミニウムを含さがそれを必要としない触媒があ る。その好例は $\mathrm{RhCl}_{8}$ 扎よびエチレン配位口ジウム錯体である。 これらの触媒杜合成が容易であり，乙かも触媒粠造が解明されて いる点からも择入反忘の研究に適した手と考えられる。Cramer は $\left[\mathrm{RhCl}\left(\mathrm{C}_{2} \mathrm{H}_{4}\right)_{2}\right]_{2}$ 錯体触某によるエチレンの二量化反応を調 ベ，アルキル中間体を経由する反応機構を提案し，さらに $\mathrm{RhCl}_{\mathbf{8}}$ 触媒化上るェテレン二量化反応す $\left[\mathrm{RhCl}\left(\mathrm{C}_{2} \mathrm{H}_{4}\right)_{2}\right]_{2}$ 錯体を経由し て進行すると推諭しているら。しかし， $\mathrm{RhCl}_{8}$ 触媒による詳細な 研究はないので本研究は $\mathrm{RhCl}_{3}$ および $\left[\mathrm{RhCl}\left(\mathrm{C}_{2} \mathrm{H}_{4}\right)_{2}\right]_{2}$ による

4) G. Wilke, B. Bogdanovic, P. Hardt, P. Heimbach, W. Keim, M. Kröner, W. Oberkirch, K. Tanaka, E.Steinvicke, D. Walter, H.Zimmermann, Angew. Chem., 5, 151(1966).

5) R.Cramer, J.Amer.Chem.Soc., 87, 4717 (1965). 
エチレン二量化反応の速度挙動を詳細に調べ，二量化反応に対す

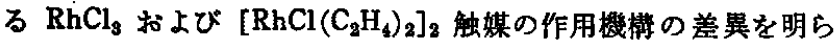
かにすることを目的とした。

\section{2 实}

験

\section{1 使用菜品}

$\mathrm{RhCl}_{8} \cdot 3 \mathrm{H}_{2} \mathrm{O}$ : 日本エンゲルハルド株式会社製, エキレン：日 本石油株式会社提供, 純度 $99 \%, \mathrm{CH}_{8} \mathrm{OH}, \mathrm{C}_{2} \mathrm{H}_{6} \mathrm{OH}$, 塩酸、ブタ ン、シクロペンタンはすべて市服試薬特級品をそのまま使用し た。

\section{2 エチレン配位ロジウム錯体 $\left[\mathrm{RhCl}\left(\mathrm{C}_{2} \mathrm{H}_{4}\right)_{2}\right]_{2}$ の合成}

Ward の方法汭にしたがって調製した。すなわち $\mathrm{RhCl}_{3} \cdot 3 \mathrm{H}_{2} \mathrm{O}$ をメタノール溶媒（本を含せ）に十分溶解させ，これにェチレン ガスを吹き込み室温で数時間静展して合成した。生成物は赤橙色 の沈股として単離することが可能で，メタノール，エーテルで数 回洗浄後真空䡎嬠した。合成したエチレン配位ロジゥム錯体の元 菜分析結果衿よび IR 娜定結果を以下に示す。

$$
\mathrm{Cl}(\mathrm{wt} \%) \quad \mathrm{H} \quad \mathrm{C} \quad \mathrm{Rh}
$$

\begin{tabular}{|c|c|c|c|}
\hline 分 析 値 & 17.93 & 4.27 & 24.10 \\
\hline 計 算 值 & 18. 23 & 4.15 & 24.70 \\
\hline
\end{tabular}

錯体の IR 吸取 実 㰸 值 $1510 \mathrm{~cm}^{-1}$

文献 值 $1515 \mathrm{~cm}^{-1}$

以上の結果仕 $\left[\mathrm{RhCl}\left(\mathrm{C}_{2} \mathrm{H}_{4}\right)_{2}\right]_{2}$ 錯体であることを示している。

\section{3 突駼方法}

二量化反応恃耐圧反応容器を使用し，加圧下で央験を行なっ た。まず, $\mathrm{RhCl}_{\mathrm{g}} \cdot 3 \mathrm{H}_{2} \mathrm{O} 1.05 \mathrm{~g}$ を $35 \mathrm{wt} \%$ 塩酸 $(10 \mathrm{ml})-工 タ$ ノール $(90 \mathrm{ml})$ の混合溶媒に溶かし触媒溶液 $(40 \mathrm{mmol} \mathrm{Rh} / l)$ ' を調整した。この溶液 $5 \mathrm{ml}$ を $30 \mathrm{ml}$ の耐环反応容器に迸入し， 液体空素を用い凍結，排気、融解をくり返し，十分脱気する。そ の後エチンンおよび内部骠準物質を既知体積の真空系に所定量遵 入し，それを液体公素でトラップした反応容器に尊入する。窒素 更围受中で閉せん後フリマゼ式佰温槽に浸し反応を開始する。こ のときをるって反開始時刻とした。通常の反応策件は反応温度 $40^{\circ} \mathrm{C}$ ，エチレン圧 $300 \mathrm{cmHg}$ である。所定反応時間後，反応容 器を液体窒素に浸し，反底を停止させる。反応容器を死体積の大 きい真空系に接続し，トラップを除き発生ガスをガスクロマトグ ラフで分析した。なお，発生ガスが均一に混合するよ5に注意す る必要があり，死体程を大きくして十分放直してからサンプリン グした。ここで液相に存在するブテン量は気相に存在するブテン 量火比較して無視できうるので，気相に発生してくるプテン量を るって生成ブテン量とした。生成ブテン量の経時変化の一例を図 1 K示す。图 1 Kおいて反応時間 30 分〜1 時間（反応初期）で プロットした点と原点とを結び，その勾配をもって初期速度と定 義した。反応中のェチレン圧はェチレン加圧下に拈ける溶媒への エチレン溶解度をあらかしめオートクレーブを用いて求め，導入 したエチレン量から溶解エチレン量を差し引いて求めた。反応中 ブタンソの発生が認められなかったので，内部標隼物質としてブタ ンを使用した。高压 $(40 \mathrm{~atm})$ での反応はオートクレーブを使用 した。この場合には反応物質扰よび内部標準物質をトラップして 满入することが困難なので内部標準物頡としてシクロペンタンを 珙び，あらかじめ触某とともに反応容器に導入し，最後にェチレ

6) R. Ward, Inorg. Chem., 1(3), 723(1962).

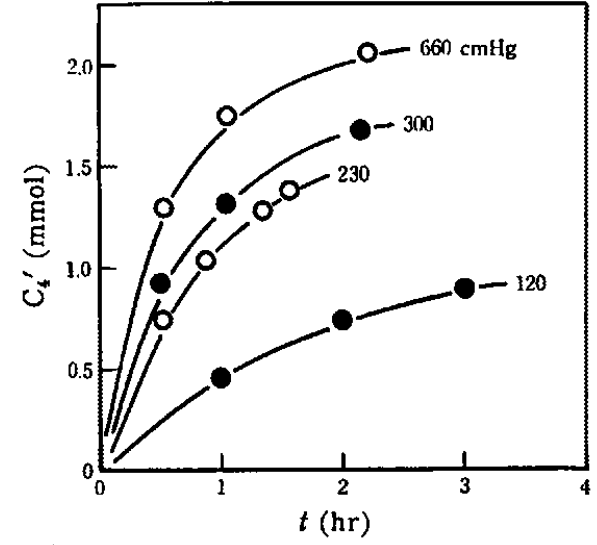

Fig. 1 The change of $n$-butene yield with reaction time under various pressure of ethylene $(\mathrm{cmHg})$

$\mathrm{RhCl}_{3} \cdot 3 \mathrm{H}_{2} \mathrm{O}(40 \mathrm{mmol}$ solution of $\mathrm{EtOH}+\mathrm{HCl}) 5 \mathrm{ml}$ reaction temperature : $40^{\circ} \mathrm{C}$

ソを導入する方法を用いた。ガスクロマトグラフ分析に使用した カラムは VZ-7, 全長 $7 \mathrm{~m}$ で $40^{\circ} \mathrm{C}$ で使用した。

\section{3 結果むよび考棎}

\section{$3.1 \mathrm{RhCl}_{3} \cdot 3 \mathrm{H}_{2} \mathrm{O}$ によるエチレンの二贯化反応}

反応は $[\mathrm{HCl}] /[\mathrm{Rh}]=10$ で行なった。この条件下では反応中に ブタンの生成は認められなかった。な扰、ガスクロマトグラフ分

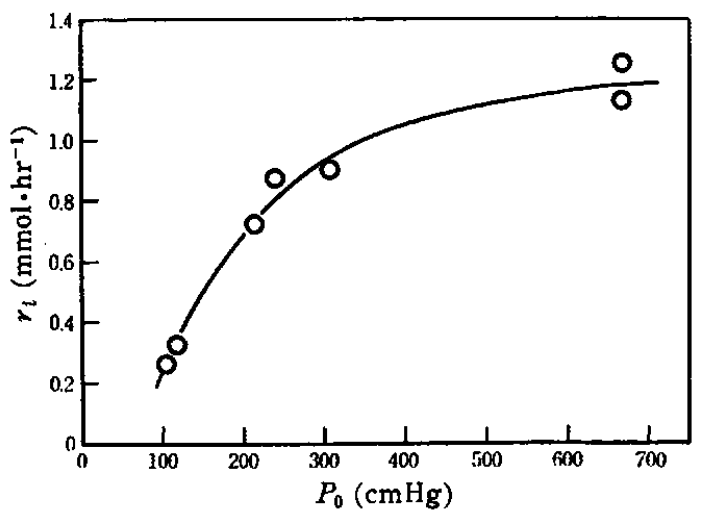

Fig. 2 The change of initial rate with ethylene pressure $\mathrm{RhCl}_{3} \cdot 3 \mathrm{H}_{2} \mathrm{O}(40 \mathrm{mmol}$ solution of $\mathrm{EtOH}+\mathrm{HCl}) 5 \mathrm{ml}$ reaction temperature $: 40^{\circ} \mathrm{C}$

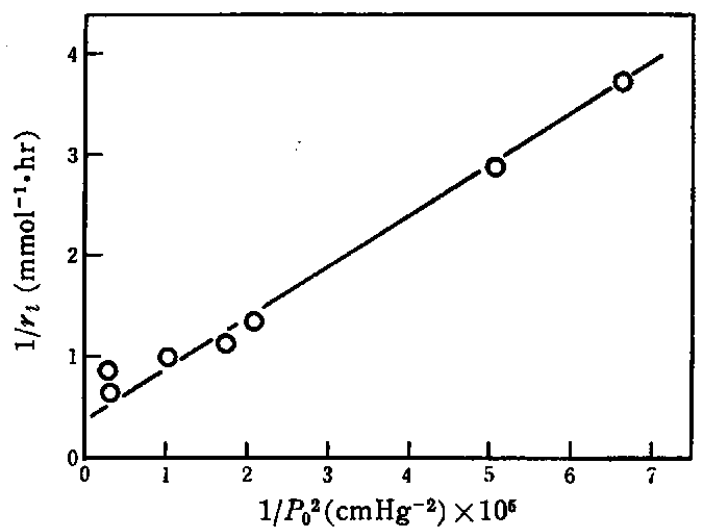

Fig. $31 / r_{i}$ vs. $1 / P_{0}^{2}$ plot

$\mathrm{RhCl}_{3} \cdot 3 \mathrm{H}_{2} \mathrm{O}(40 \mathrm{mmol}$ solution of $\mathrm{EtOH}+\mathrm{HCl}) 5 \mathrm{ml}$ reaction temperature $: 40^{\circ} \mathrm{C}$ 
析により $C_{6}$ 成分と思われる生成物が多少認められたがその量は 生成プテン照に比校して無視しらることを確かめてある。ブテン 生成の初期速度（ $\left.r_{\imath}\right)$ と反忘中のエチレン玨との関係を四 2 に示 す。この関係はつぎの（1）式で整理できる。こことは（1） 式を変形した（2）式のプロット（図3）がよい正線性を示して いることから碓かめられる。

$$
\begin{gathered}
r_{i}=k \frac{K P_{0}^{2}}{1+K P_{0}^{2}} \\
\frac{1}{r_{i}}=\frac{1}{k K P_{0}^{2}}+\frac{1}{k}
\end{gathered}
$$

ここで， $k, K:$ 速度定数, $P_{0}:$ エチレン初压である。

生成したブテンはほぼ平衡組成 $\left(40^{\circ} \mathrm{C} て ゙ の\right.$ 平衡組成 : 1-ブテ ソ 7\%, trans-2-ブテン 71\%, cis-2-ブテン 22\%) であり，平 衡值からのずれが最大の場合です，1-ブテン: trans-2-ブテン： cis-2-ブテン=2:5:3であった。(acac $)_{2} \mathrm{Rh}\left(\mathrm{C}_{2} \mathrm{H}_{4}\right)_{2}$ 鍇体ではエ チレン増大にとすないブテン異性化反応が抑制されることが報 告されている7。そこで $\mathrm{RhCl}_{3} \cdot 3 \mathrm{H}_{2} \mathrm{O}$ ですエチレン压增大にとる ない異性化反応が抑制される可能性があるので 1ーブテンの異性 化反応へのエチレン添加效果を調へたところ異性化反応が抑制さ れることを確かめた。この事夷を利用してつぎのように高ニチレ ン压を用い巽性化反応を排制して二量化反応を調べた。すなわ ち, エチンソ压 $40 \mathrm{~atm}$, 室温で反応を行ない, 内部標淮物質と してシクロペンタンを用いた。生成ブテン量の経時変化を図 4 K 示す。この場合には土チレン䓦入時をるって反应開始洔刻とし た。ここでグラフが原点を通らないのは反応開始時刻の決め方に よるるのと思われる。図4 はきわめて低反応率領域であるので, エチレン压は十分高压である。したがって異性化反応は十分抑制 されている条件であるから 1-ブテン, trans-2-ブテン, cis-2-ブ テンが独立に生成していることがわかる。以上の結果㤆応経路 （a）を仮定することによって説明できる。

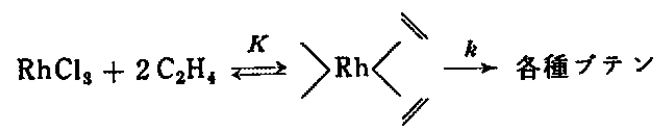

反応系中にェタノール，氷が存在するので $\mathrm{RhCl}_{3}$ と $\mathrm{C}_{2} \mathrm{H}_{4}$ との

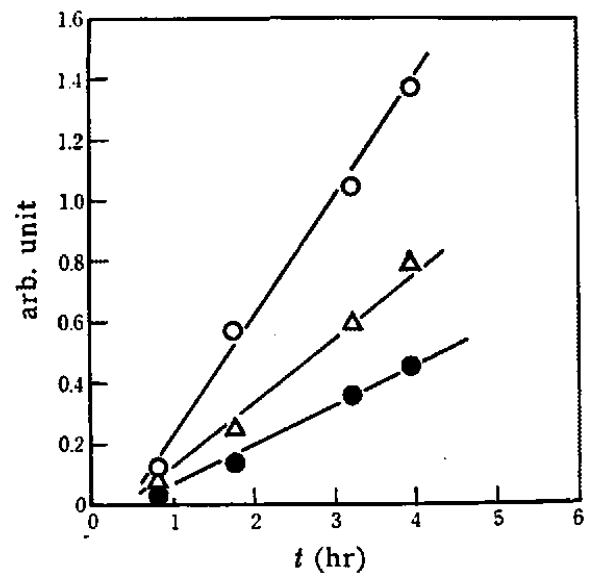

Fig. 4 The change of $n$-butene yield with reaction time $\mathrm{RhCl}_{3} \cdot 3 \mathrm{H}_{2} \mathrm{O}$ ( $40 \mathrm{mmol}$ solution of $\mathrm{EtOH}+\mathrm{HCl}$ ) $15 \mathrm{ml}$ reaction temperature : room temperature ethylene pressure: $40 \mathrm{~atm}$ $\mathrm{O}: 1$-butene, $\Delta:$ cis-2-butene, trans-2-butene

7) R.Cramer, J.Amer. Chem.Soc., 88, 2272(1966).
反応で $\mathrm{HCl}$ が生成することが考えられる。しかし，あらかじめ $\mathrm{HCl}$ を反応系内に入れて放るので $\mathrm{HCl}$ の䟴度変化は無視でき， 鍇体形成の平衡定数Kの内容に書き入れる必要はない。ロジウム

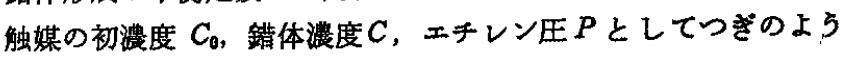
に表わせる。

$$
K=\frac{C}{\left(C_{0}-C\right) P^{2}}
$$

したがって

$$
C=\frac{K P^{2} C_{0}}{1+K P^{2}}
$$

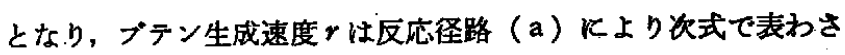
れることになる。

$$
r=k C=\frac{k K P^{2}}{1+K P^{2}} C_{0}
$$

反応初期に括いては $P=P_{0}$ となり（1）式と一致する。つぎに 各種ブテンが独立に生成するための中間体の型を考える。通常ブ テンが金属に配位している状態として $\pi$ ーアリル型とアルキル型 の 2 種類の型が知られている。異性化反応が抑制されている状態 でアルキル型中間体を経由するすのであれば 1-プテンのみが生 成するはずである。この場合，実測された各生成ブテンの割合は 1-ブテン : trans-2-ブテン : cis-2-ブテン $\div 4: 2: 1$ であった。 さらにアルキル中間体すなわち半水素化状態を維由する反応は水 素を添加すると反応速度が增大することが多い。二盢化反応中に 水素を添加しブテンの生成速度を測定した結果，水案による影留 は認められなかった。なおこの場合ブタンは生成しない。以上の ことから中間体忙 $\pi$ ーアリル型㝵であると考えた。初期速度の温 度依存性を調べ，見かけの活性化エネルギーは $13: 6 \mathrm{kcal} / \mathrm{mol}$ 得られた（図 5 )。

\section{$3.2\left[\mathrm{RhCl}\left(\mathrm{C}_{2} \mathrm{H}_{4}\right)_{2}\right]_{2}$ 鏳体によるエチレンの二要化反応}

この錯体を用いたエチレンの二量化反応る $\mathrm{RhCl}_{3} \cdot 3 \mathrm{H}_{2} \mathrm{O}$ の场 合と同様の操作条件下で行なった。ブテン生成量の経 時变化は $\mathrm{RhCl}_{3} \cdot 3 \mathrm{H}_{2} \mathrm{O}$ の場合と類似している。プテン生成初期速度のエチ レン压依存性は図6のようにェチレン瓦に一次である。高エチレ ン圧 $(40 \mathrm{~atm})$ に甜けるブテン組成の释時変化を図 7 に示す。反 応初期火抹いては 1-ブテンのみ, その後 trans-2-ブテンと cis2-ブテンがほば等モルの割合で生成してくることがわかる。

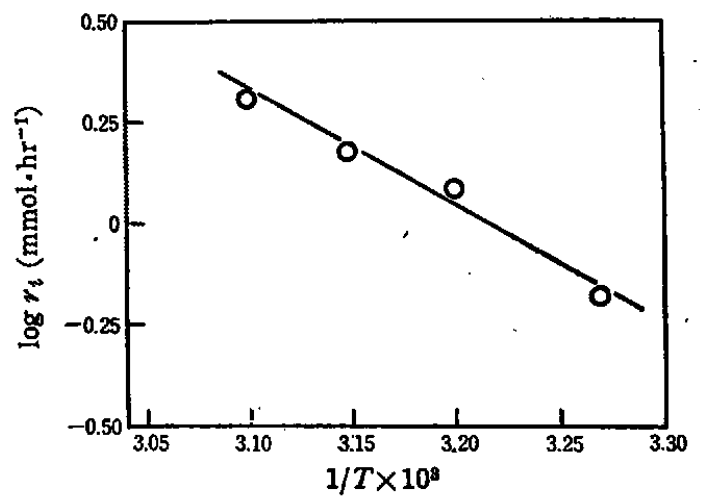

Fig. 5 Arrhenius plot for the dimerization of ethylene $\mathrm{RhCl}_{3} \cdot 3 \mathrm{H}_{2} \mathrm{O}$ (40 mmol solution of $\left.\mathrm{EtOH}+\mathrm{HCl}\right) 5 \mathrm{ml}$ ethylne pressure : $300 \mathrm{cmHg}$

8） $\pi$ フリル型の存在はニッケル錯体の NMR 研究9から立哃 されている。

9) H. Bönnemann, Angew. Chem., 82, 699(1970). 


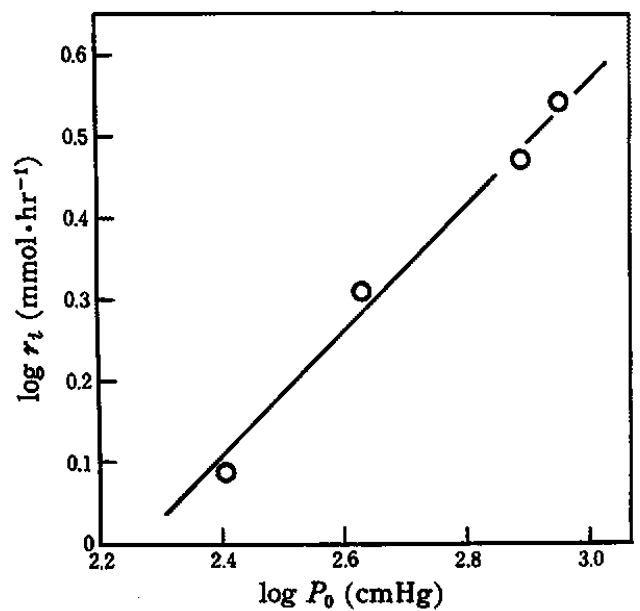

Fig. 6 The variation of initial rate with ethylene pressure

$\left[\mathrm{RhCl}\left(\mathrm{C}_{2} \mathrm{H}_{4}\right)_{2}\right]_{2}(40 \mathrm{mmol}$ solution in $\mathrm{EtOH}+\mathrm{HCl}) 5 \mathrm{ml}$ reaction temperature : $40^{\circ} \mathrm{C}$

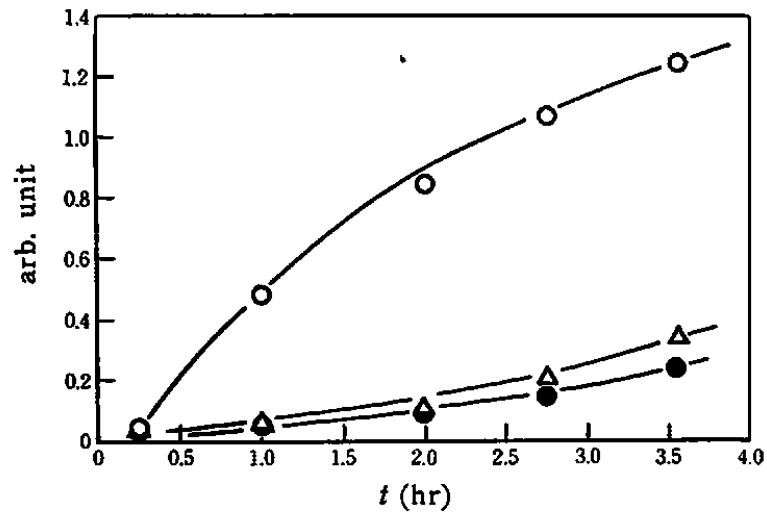

Fig. 7 The change of $n$-butene yield with reaction time

$\left[\mathrm{RhCl}\left(\mathrm{C}_{2} \mathrm{H}_{4}\right)_{2}\right]_{2}(40 \mathrm{mmol}$ solution of $\mathrm{EtOH}+\mathrm{HCl}) 15 \mathrm{ml}$ reaction temperature : room temperature ethylene pressure : $40 \mathrm{~atm}$

$O$ : 1-butene, $\Delta:$ trans-2-butene, $:$ cis-2-butene

$\mathrm{RhCl}_{3} \cdot 3 \mathrm{H}_{2} \mathrm{O}$ 触媒の場合には各ブテンが独立に生成したのに対し $\left[\mathrm{RhCl}\left(\mathrm{C}_{2} \mathrm{H}_{4}\right)_{2}\right]_{2}$ 触某の場合に山まず 1-ブテンがついでその異性 化により trans-2-ブテンと cis-2-ブテンが生成するといら違い がある。以上の事実は $\left[\mathrm{RhCl}\left(\mathrm{C}_{2} \mathrm{H}_{4}\right)_{2}\right]_{2}$ による二量化反応では Cramer の提案したアルキル中間体らす経由する反応機構が妥当 であることを示している。ロジウム錯体をエタノール溶媒に溶解 するとエチレンがロジウム $1 \mathrm{~mol} \mathrm{あたり} 2 \mathrm{~mol}$ 発生する。さら にエキレン加圧下ではロジウム錯体が単離できる。すなわちエチ

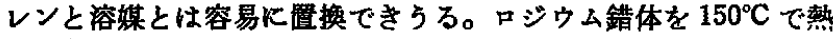
分解するとエチレンのみ発生し，ブテンの発生が認められないこ

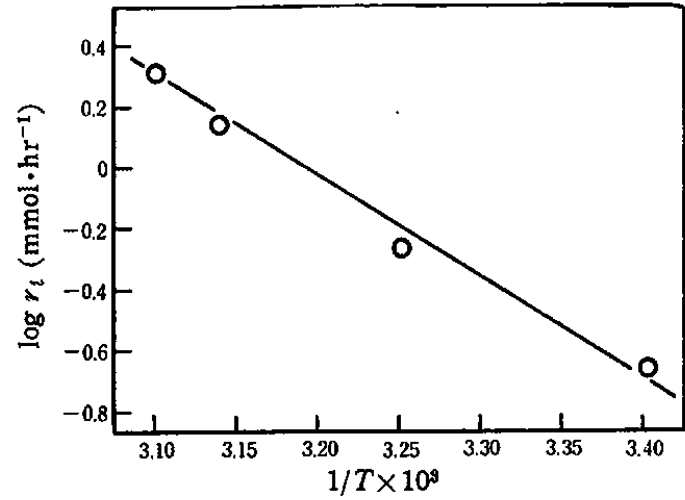

Fig. 8 Arrhenius plot for the dimerization of ethylene $\left[\mathrm{RhCl}\left(\mathrm{C}_{2} \mathrm{H}_{4}\right)_{2}\right]_{3}(40 \mathrm{mmol}$ solution of $\mathrm{EtOH}+\mathrm{HCl}) 5 \mathrm{ml}$ ethylene pressure : $300 \mathrm{cmHg}$

とから，配位しているェチレン同志が反応するのではなく，配位 エチレンと気相のエチレンとが応する。さらに二量化反応速度 は土チレン压に一次であり，反応初期に 1-ブテンしか生成しな いことから以下の機搆を考えた。

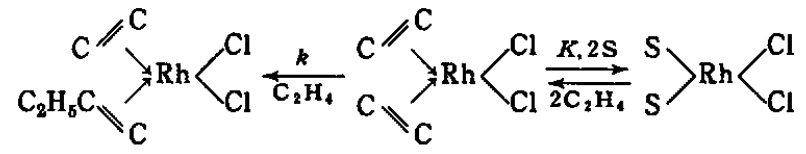

[B]

[A]

ここで， $\mathrm{S}:$ 溶媒， $K:$ 平衡定数， $k$ : 速度定数である。

[B]の生成は[A]へのエチレン簐突によると考えてよい。口 ジウム錯体濃度 $C$, 初濃度 $C_{0}$ ，エチレン圧 $P$ とすれば，上記反 応機錸より

$$
\begin{aligned}
& K=\frac{\left(C-C_{0}\right) P^{2}}{C S^{2}} \\
& C=\frac{C_{0} P^{2}}{P^{2}-K S^{2}}
\end{aligned}
$$

ここで $P^{2} \gg K S^{2}$ ならば

$$
\begin{aligned}
\text { 初期速度 } & =k P_{0} C \\
& =\frac{k C_{0} P_{0}^{2}}{P_{0}^{2}-K S^{2}} P_{0} \\
& \doteqdot k P_{0} C_{0}
\end{aligned}
$$

となりエチレン压に一次となることが理解できる。すなわち気相 にエチレンが存在する反纫条件下では配位エチレンが溶媒によっ てほとんど置換されていないことを示している。なお，初期速度 の温度依存性より活性化エネルギーは $14.7 \mathrm{kcal} / \mathrm{mol}$ と得られた （図 8)。この数值は金属ーアルキル結合あるいは金属ーヒドリド結 合間へのオレフィン㧴入反灾の活性化エネルギー6)10) とよく一致 している。

10）河本圭司, 今中利僄, 寺西士一郎, 日化，89，639(1968). 


\title{
Ethylene Dimerization with Rhodium Complex Catalysts ${ }^{\dagger}$ \\ Ichiro OKURA and Tominaga KEII \\ Department of Chemical Engineering, Tokyo Institute of Technology ; \\ Ookayama, Meguro-ku, Tokyo, Japan
}

The kinetics of ethylene dimerization with Rhodium complex catalysts has been carried out to clarify the reaction mechanism.

In case of $\mathrm{RhCl}_{8}$-catalyst, the rate of butene formation can be represented by

$$
\frac{k K P^{2}}{1+K P^{2}} C_{0}
$$

where $C_{0}$ is the concentration of the catalyst, $P$ ethylene pressure and $k, K$ are constant. It was found that ethylene retarded the butene isomerization reaction rate. Under such conditions that the butene isomerization is forbidden (under the ethylene high pressure), 1-butene, trans2 -butene and cis-2-butene were formed concurrently. A reaction mechanism via $\pi$-allyl intermediate was proposed, on the basis of the experimental results.

In the case of $\left[\mathrm{RhCl}\left(\mathrm{C}_{2} \mathrm{H}_{4}\right)_{2}\right]_{2}$-catalyst, 1-butene was the only initial product and cis- and trans -2 -butene were produced at the equal rates by the isomerization of 1-butene. Since the rate of butene formation was first order with respect to ethylene pressure, the dimerization appears to occur via an alkyl intermediate which was formed between ethylene and the catalyst, and the formation of the intermediate seems rate-determining.

† Reaction Mechanism on Rhodium Complex Catalysts. I.

\section{酸化的脱水素芳香族化触媒のプロピレンによる還元反応}

\author{
（1971 年 8 月 31 日 受理）
}

\author{
江頭諴・浦部素值・清山哲郎*
}

低般オレフィンの酸化脱水菜芳香族化反応の触媒作用に関して，リン酸ビスマス触媒 $(\mathrm{Bi} / \mathrm{P}=2)$ と少量の $\mathrm{Na}_{2} \mathrm{O}$ を 含む酸化スズ触媒のブロビレンによる迶元反応を 500 800 C で調べた。

リン酸ビスマス触媒は, 接触酸化の反応条件下では $3 \mathrm{Bi}_{2} \mathrm{O}_{3} \cdot \mathrm{P}_{2} \mathrm{O}_{5}$ (I)，2 $2 \mathrm{Bi}_{2} \mathrm{O}_{3} \cdot \mathrm{P}_{2} \mathrm{O}_{6}$ (II)，モナッァイト型の $\beta-$ $\mathrm{BiPO}_{4}$ (III)，高温型の $\gamma-\mathrm{BiPO}_{4}(\mathrm{~N})$ 扰よび $\gamma-\mathrm{Bi}_{2} \mathrm{O}_{\mathrm{s}}(\mathrm{V})$ の混合物であるが, 還元反応によってI扰よび金属 $\mathrm{Bi}$ と III (または $\mathrm{N}$ ) K, Vは金属 $\mathrm{Bi}$ に変わる。つまり $\mathrm{Bi}^{9+} \longrightarrow \mathrm{Bi}^{0}$ の反応が起こる。酸化スズは $\mathrm{Sn}^{4+} \longrightarrow \mathrm{Sn}^{0}$ の 反応により金属 Sn 飞還元される。一方, プロピレンからは二酸化炭素, ペンぜンが生成し, 罢元反応初期のそれら の選択率は接触酸化の場合とほぼ同じである。これらの事実から酸化脱水莱芳香族化反応你媒の酸化遥元サイクル $\left(\mathrm{Bi}^{3+} \rightleftarrows \mathrm{Bi}^{0}\right.$ あるいは $\left.\mathrm{Sn}^{4+} \rightleftarrows \mathrm{Sn}^{0}\right)$ で進んでいるといえる。還元の進行にとるなら二酸化孷案生成量とへンゼン 生成量の变化はたがいに異なる。前者はいすれの場合にす単調に減少するのに対し，後者は這元速度が比較的小さい 低温では前者よりる速く，また高温では前渚よりもゆるやかに減少する。

\section{1 藉言}

プロピレンやブテンなど低級オレフィンをリン酸ビスマスや 酸化スズ触媒上で酸化すると、ベンゼンやキシレンなどの芳香族 化合物が生成する1”。の酸化脱水素芳香族化反応はオレフィン のアリル位から水素が1個引きぬかれてアリル中間体が生じこ れが二量化，芳香族化するものであり，Sohio 法以来の種々の多 成分系酸化物触媒上でのアクロレインやアクリロニトリルヘの酸

* 九州大学工学部応用化学教室, 福岡市箱崎町

1) T.Sakamoto, M.Egashira, T.Seiyama, J. Catal., 16 , 407(1970).
化反応などと同じ型の，いわゆるアリル型酸化に分類できる反応 である。したがって本反応打ける触媒作用の解明は，広くアリ ル型酸化に打ける繦媒作用の体系化に結びつくるのとして興味深 い。この観点から、著者らはこれまで主として酸化ビスマス禾お゙ よび酸化スズ系触媒のプロピレン酸化能について検討を進め, 2 種のアリル型酸化反応の関係について若干の知見を得だ),9す なわち酸素酸ビスマス塩はいずれすアリル型酸化活性を示し、か 2）江頭 羬, 麻生 功, 宇田泰三, 坂本光久, 清山哲郎, 触、
媒, 12，92(1970).

3) T.Seiyama, M.Egashira, T.Sakamoto, 1. Aso, J.Catal., 投稿中. 